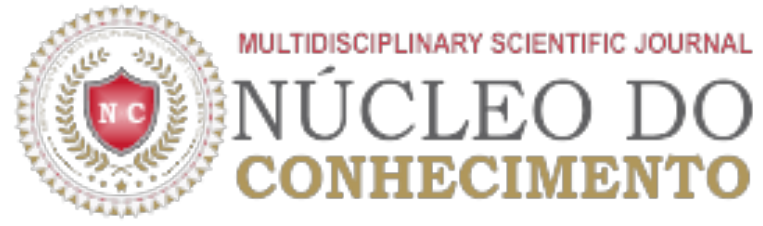

\section{A Luz como Intervenção Urbana}

\author{
GONÇALVES, Camila Matos Maia de Castro ${ }^{[1]}$
}

GONÇALVES, Camila Matos Maia de Castro. A Luz como Intervenção Urbana. Revista Científica Multidisciplinar Núcleo do Conhecimento. Ano 03, Ed. 06, Vol. 05, pp. 25-41, Junho de 2018. ISSN:2448-0959

\section{Resumo}

O presente artigo consiste em uma proposta de análise da forma que a iluminação pública está sendo inserida nas grandes metrópoles. Desde o processo histórico com as descobertas das primeiras fontes de luzes rudimentares, até o presente momento, com as lâmpadas de alta eficiência e durabilidade. Neste projeto de pesquisa serão propostas discussões sobre os avanços dos espaços públicos à noite perante a diversidade luminotécnica. Objetiva-se apresentar os principais fundamentos para se planejar uma boa iluminação urbana, que respeita a construção da ambiência em foco na satisfação dos usuários. Especialmente em como as experiências sociais notívagas podem trabalhar como fator relevante para a iluminação da cidade. Também serão salientados alguns problemas que podem ser diagnosticados nos grandes centros, como por exemplo, a poluição noturna. Para efeito de demonstração serão utilizados três projetos de intervenção urbanística que obtiveram sucesso. E a partir de pesquisas bibliográficas, revistas, estudo de imagens e vídeos pode-se configurar a cidade contemporânea por intervenção da luz.

Palavras-chave: Luz, Cidade, Iluminação, Eficiência, Ambiência, Noite.

\section{Introdução}

O rápido crescimento e expansão das cidades forjam emergentes tecnologias, reconhecimento por saúde social, necessidade de áreas mais sustentáveis e ambientes urbanos que transcendem funções de infindas oportunidades que a noite outorga. "A importância da iluminação pública nas considerações do problema e justifica o lugar de destaque que a luz urbana assume nas plataformas políticas e governamentais, nas demandas dos habitantes e no imaginário popular" (CARVALHO; MARTINS; VANDERLEI, 2008).

Diferentemente da luz solar, que é proveniente do meio natural, a luz artificial possui características variantes quando se diz respeito ao aspecto e manipulação exercida. Ir além do desempenho funcional e investir em infraestruturas mais inteligentes que possuem capacidade de serem programadas para efetuar 
de acordo com as instâncias, criam-se espaços abertos com vividas funções noturnas.

Saber explorar a comunicação e o comportamento social sem danificar o bem-estar dos demais grupos perimetrais é respeitar o contexto histórico. Reconhecer o processo de cooperação entre as partes interessadas é cultivar laços entre a comunidade e o local que sofrerá intervenção. Não mais que um sistema que estabelece interdependência, a luz pública e privada devem coexistir sem haver disputas, mas sim de forma homogênea.

As fontes luminosas são capazes de causar efeitos múltiplos na psicologia, sensorialíssimo, espaços e simbologias. É a capacidade de qualificar a ambiência como resposta ao sentimento visual que o corpo exala.

Os benefícios que a iluminação artificial traz, promovem reações em cadeia na autoestima dos cidadãos, que ao desempenharem o papel moldador em como a cidade será olhada, admitem ter orgulho do próprio meio. Os significados da luz no espaço são as réplicas da cidade aos acontecimentos do mundo moderno. Como bem sintetiza a designer Florence Lam (2015):

Iluminação urbana não é apenas sobre a satisfação das necessidades de segurança por meio do cumprimento de código, ou conseguir um efeito estético. Ele apresenta uma oportunidade significativa para melhorar substancialmente a qualidade de vida dos cidadãos urbanos. Devidamente considerados, a iluminação pode impactar positivamente a "arquitetura total" das nossas cidades; Reforçar os princípios de design urbano, aumentando a experiências culturais e incentivar a interacção social. (LAM, 2015).

\section{A luz como engrenagem da história}

Ao traçar um panorama cronológico do desenvolvimento urbano sob a ótica da luz artificial a partir da ideia conceptiva até a pluralização factual, podemos compreender as necessidades e desejos comportamentais atuais que envolvem alguns espaços públicos que são transmudados em zonas estéreis ao anoitecer, compelidos de temor, ansiedade e hostilidade. Esta indispensabilidade luminosa pode ser visualizada desde a pré-história no qual o homem se relaciona com a luz natural e artificial como um meio evolutivo. Fator que fora decisivo com o domínio da produção do fogo que o fez desenvolver-se biologicamente e socialmente perante outros seres. A importância da descoberta trouxe a raça humana melhores condições alimentares, conforto térmico e segurança. $\mathrm{O}$ fogo passou a ser um instrumento de defesa contra o que a noite trazia, afastando os animais ou até mesmo outros grupos de indivíduos que poderiam ser uma ameaça.

Uma vez que a forma mais primitiva da espécie humana se desenvolveu, com ela nasceram conceitos de organização social e de civilizações. Por meio da criação das cidades, o comércio surge como atividade complexa e especializada. Entretanto esse crescimento sociocultural era limitado a um determinado período, o dia. A luz solar permitia o emprego melhor das tarefas, interações sociais e funcionamento da comunidade, e ao cair da noite, a maioria das atividades eram suspensas e somente restava permanecer em abrigos, dormir e esperar pelo amanhecer. Por essa razão a crescente necessidade do homem de produzir e melhor aproveitar o tempo o levou a buscar soluções para a escuridão.

Martins (2011) aborda que na antiga Mesopotâmia, ano de 8.000 A.C., "pratos ou cubas com gordura animal, era colocada uma fibra vegetal que funcionava como fonte de luz". Diferentemente do Egito 
antigo que já utilizava pavio de algodão inserido em parafina sólida, a vela.

Datam-se a partir da Idade Média, entre 476-1500 D.C., as primeiras soluções rudimentares da iluminação pública. Além das velas, foram utilizadas fibras torcidas embebidas em material inflamável modelada em formato de tocha. Este aparato permitia que as pessoas circulassem durante a noite com uma determinada visibilidade e autonomia. Ainda assim, não era um recurso eficaz e ergonômico. Até o século XV a iluminação das ruas era de responsabilidade dos cidadãos, sendo submetidos a severas penalidades, de acordo com as leis que estavam em vigor, para aqueles que as infringissem. Com o passar do tempo a indispensabilidade por uma iluminação pública de qualidade sobrelevou a Inglaterra de 1415, sob pressão dos comerciantes londrinos indignados com o aumento da taxa de criminalidade da época, a ser o primeiro reino europeu a oferecer luminárias feitas com lâmpadas de óleo de azeite financiadas pela monarquia regente (WILLIANS, 2016). 


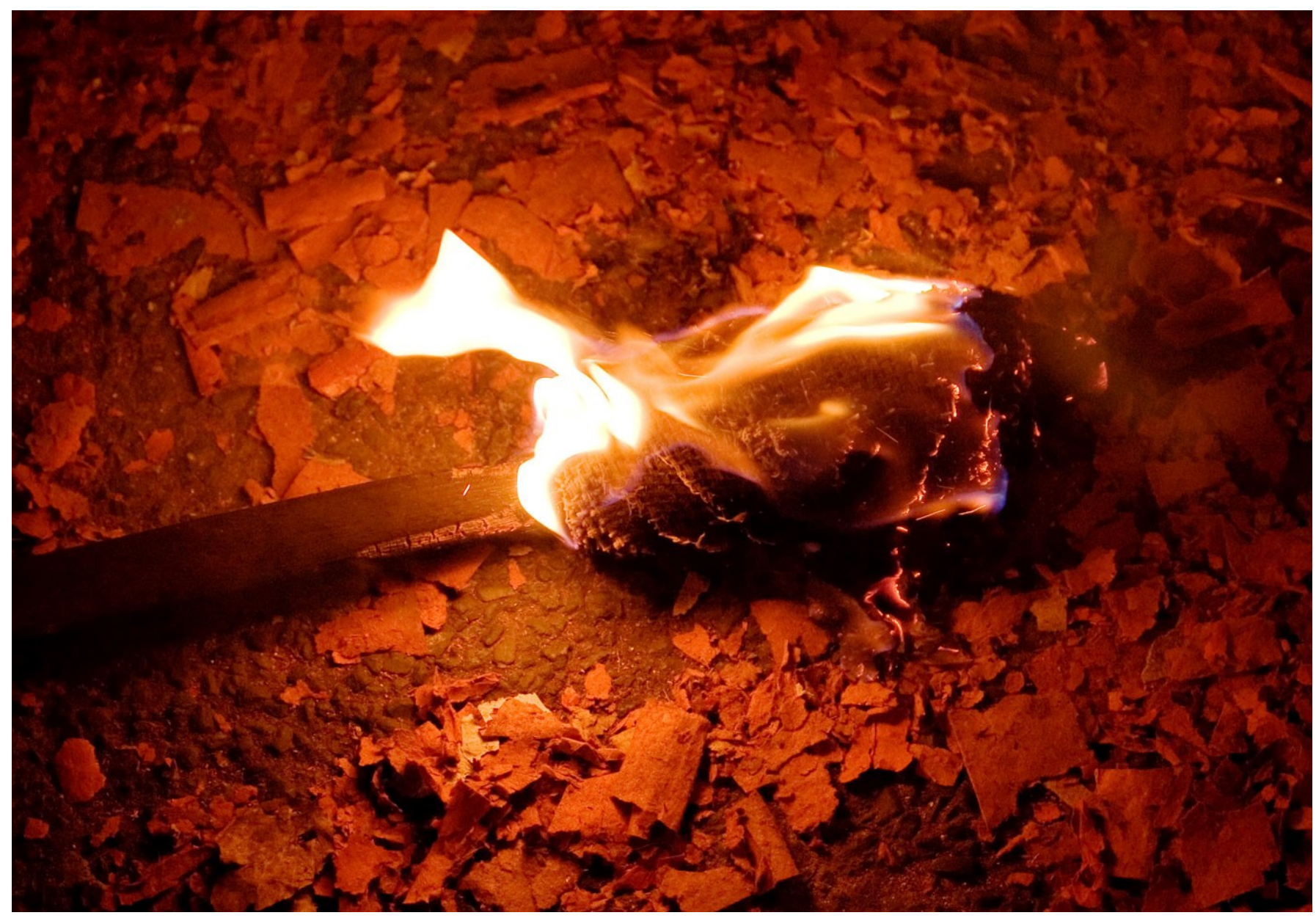

Figura 1 - Representação do aparato utilizado na Idade Média para a iluminação. Fonte: https://commons.wikimedia.org/wiki/File:Lewes_Bonfire,_discarded_torch.jpg (2005)

No período colonial o Brasil de 1763, possuía não mais que lampadários posicionados nas entradas dos edifícios religiosos e alguns oratórios localizados em certas esquinas. E como previsto cabia a população acender os candeeiros de gordura de peixe ou velas de cera. A primeira inciativa de iluminação pública na colônia portuguesa foi na capital da época, Rio de Janeiro, ordenado pelo Vice-Rei Dom José Luiz de Castro, mais conhecido pelo título real de Conde Rezende, que concedeu no ano de 1794 à cidade cerca de 100 luminárias de óleo de azeite que foram instalados nas principais ruas. A responsabilidade da tarefa operacional dos lampiões foi inicialmente designada aos escravos, posteriormente em 1822 foi criada a profissão de acendedores de lampião, profissionais contratados pelo município com única atribuição de acender os lampiões no início da noite, apagar ao amanhecer e gerir a manutenção do equipamento (ESTEVES, 2010). 


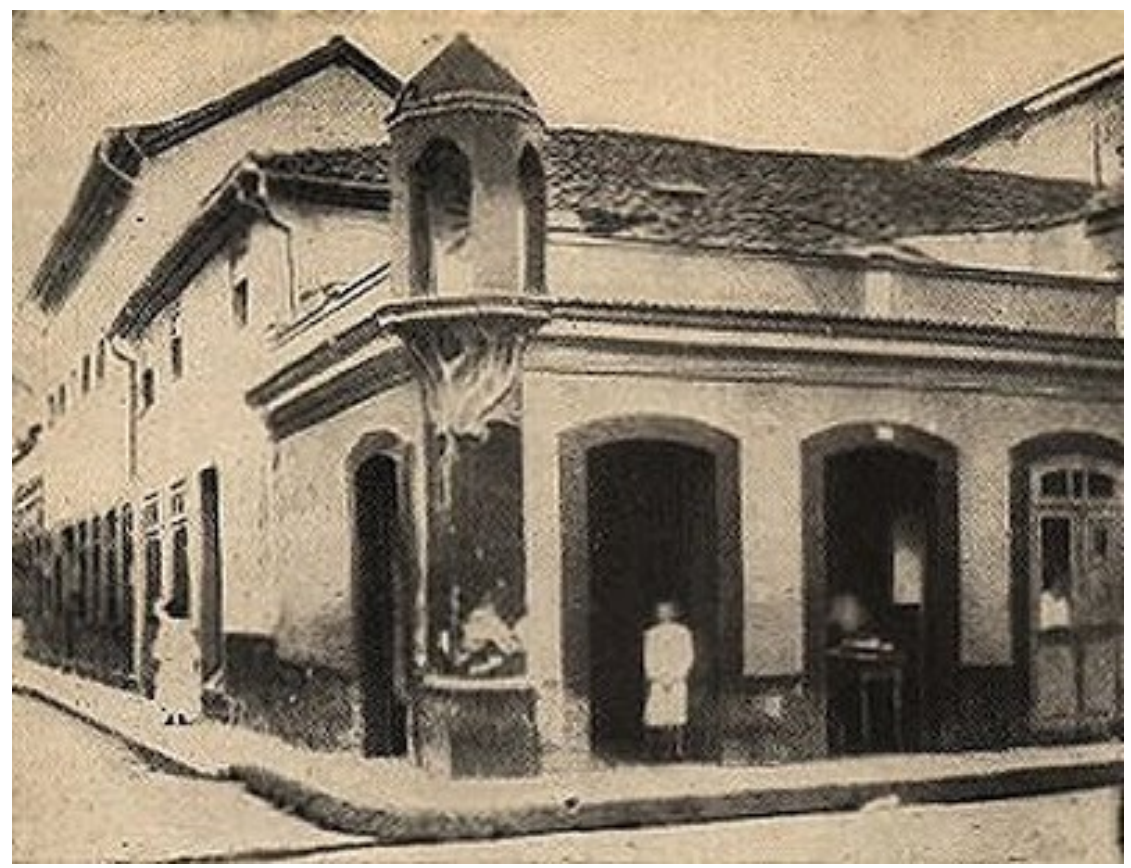

Figura 2 - Lampadário que existiu na esquina das ruas da Alfândega e Regente Feijó em 1820, Rio de Janeiro. Fonte: http://riocurioso.blogspot.com.br/2008/02/iluminao-no-rio-de-janeiro-i.html (2008)

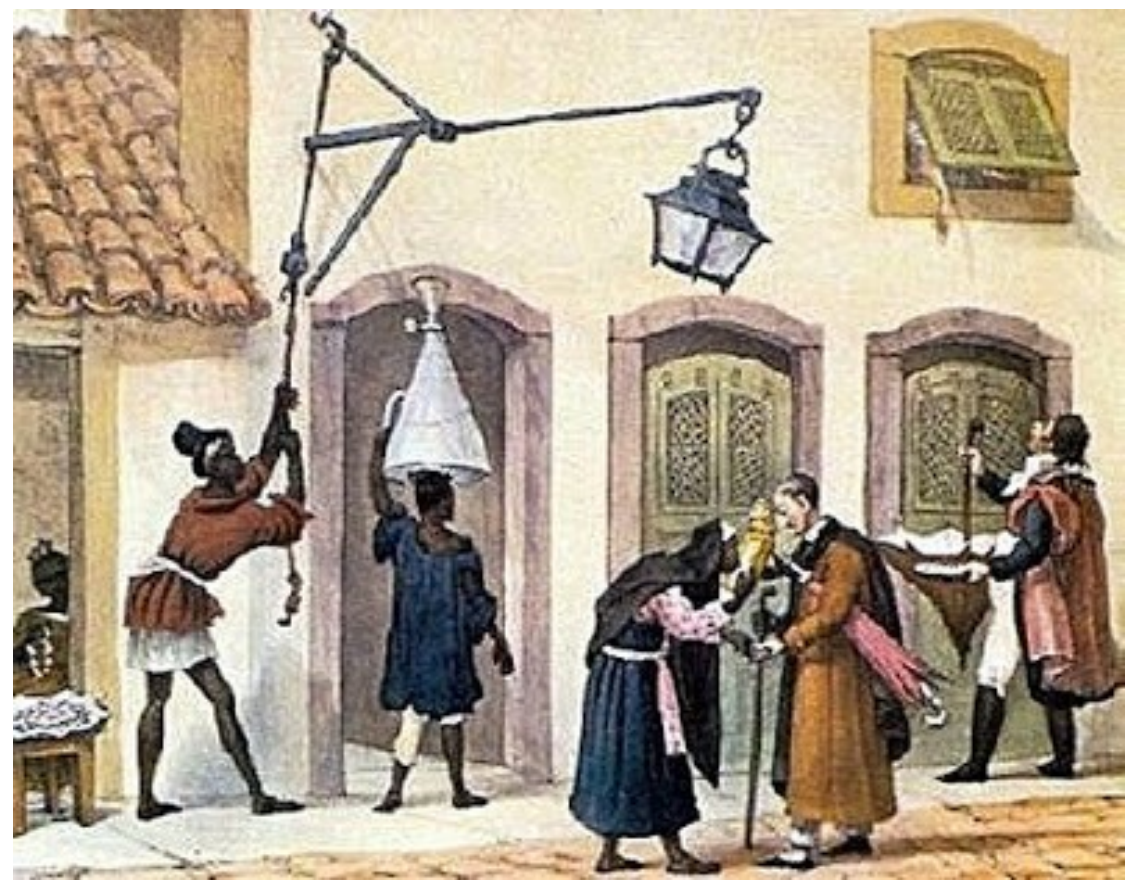

Figura 3 - Luminárias de óleo sendo acendidas por escravos, Rio de Janeiro. Fonte: http://rio-curioso.blogspot.com.br/2008/02/iluminao-no-riode-janeiro-i.html (2008)

Por conseguinte, com o surgimento das experiências precursoras do engenheiro francês Philippe Lebon, a iluminação melhorou consideravelmente com a descoberta do gás de carvão, ou gás hulha, como fonte iluminante eficiente. Outro que contribuiu em pesquisas e experimentos no campo foi o engenheiro escocês Willian Murdock, que construiu maquinários com fundamentos parecidos. Ambos foram fundamentais para a ampliação e desenvolvimento da tecnologia a gás, cujo invento despertou grande 
interesse da Inglaterra nos anos posteriores. Sendo assim, aproximadamente entre o período de 1800 a 1810, surgiram as primeiras companhias comerciais de iluminação a gás. O empresário alemão Frederick Albert Windsor, divulgou pela Inglaterra os benefícios da iluminação gerada pela combustão do carvão. E em Londres, 1809, fundou a primeira companhia de fornecimento público de gás, The Gas Light and Coke Company. Em 1823, toda a Grã-Bretanha já havia adotado a nova tecnologia para as ruas e residências, concomitantemente os demais países da Europa também se movimentaram para construir a infraestrutura essencial do novo futuro apresentado à luz urbana (BERNARDO, 2007:146).

O sistema a gás de hidrogênio carbonado chegou ao Brasil pelas mãos do Barão de Mauá em 1850, com a proposta de iluminar a cidade do Rio de Janeiro. Fábricas de carvão mineral foram instaladas na extensão da atual Av. Presidente Vargas. Como resultado, foram erguidos dois gasômetros, porém, somente em 1854 foram concluídas as implantações da iluminação pública a gás na cidade. Pioneiro em usar inicialmente uma rede de $20 \mathrm{~km}$ de tubulações de ferro que alimentavam combustores que geravam iluminância de igual valor a seis velas de cera por unidade, Visconde de Mauá, obteve por 25 anos o monopólio na exploração do setor. Ainda que tenha sido um grande salto para o progresso e crescimento significativo do comércio e cultura noturna, a cidade suscitou divisas temporais e socioeconômicas. As áreas mais periféricas permaneceram isoladas com pouca claridade e iluminação improvisada em candeeiros à base de óleos vegetais ou animais, enquanto a parte mais nobre usufruía do progresso europeu em terras brasileiras (MARTINS, 2011).

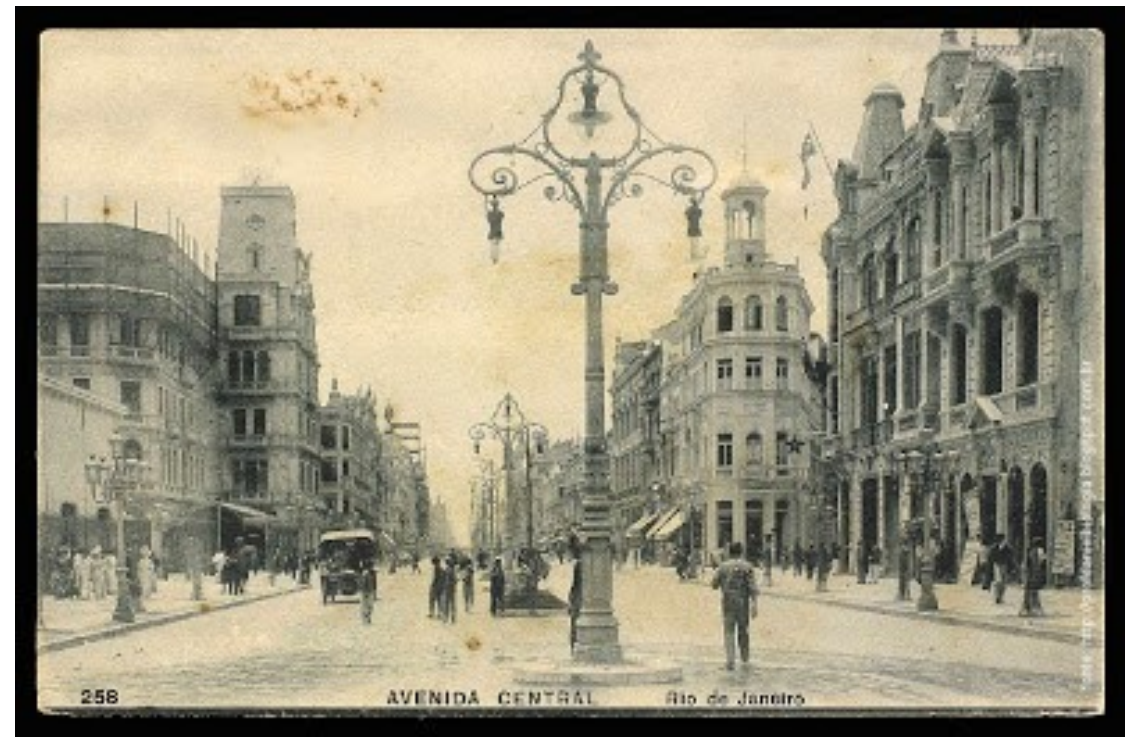

Avenida Central em 1903, Rio de Janeiro. Fonte: http://museubenjaminconstant.blogspot.com.br/2013/07/curiosidades-iluminacao-do-rio-de.html (2013)

Tudo levava a crer que a iluminação produzida por combustíveis naturais era a grande descoberta da modernidade e que não haveria em breve outra solução tão eficaz ao ponto de ultrapassa-la. Durante o período de 1802 a 1840, grandes avanços ocorreram no campo científico dos fenômenos elétricos e magnéticos. Cientistas como André-Marie Ampère, George Simon Ohn, Johann Friedrich Karl Gaus e Humphry Davy, foram fundamentais para estas descobertas tecnológicas.

Sendo um dos primeiros a fazer demonstrações para uma banca, Humphry Davy executou em 1810 perante aos membros da Royal Institution, o experimento do arco voltáico, que consistia em uma potente 
bateria ligada a hastes, ou varetas, de carvão de madeira, as quais formavam um arco de $10 \mathrm{~cm}$ que entravam rapidamente em combustão, ao mesmo tempo que reproduzia uma luz pujante fundida a uma liga de irídio e ósmio com outras substâncias refratárias. Todavia, apenas em 1844 surgiram as primeiras aplicações da luz elétrica. O físico e astrônomo Jean Bernard Léon Foucault, realizou uma série de investigações sobre a intensidade da luz do sol comparando-a com o carbono, permitindo este a criação de uma lâmpada similar ao arco de Davy. As lâmpadas de Foucault tinham como uma das diferenças a utilização de varetas de carvão de retorta, subproduto das caldeiras que produziam gás de iluminação, em substituição as hastes de carvão de madeira. Tal inovação foi importante para o crescimento da emergente indústria das lâmpadas elétricas, que a cada ano aumentavam o número de patentes com soluções tecnológicas cada vez mais eficazes (BERNARDO, 2007:151).

O primeiro experimento realizado em espaço público foi em dezembro de 1844 pelo oculista Deleuil, na Praça da Concórdia em Paris. Deleuil utilizou uma lâmpada potente de arco que provocou grande espanto e admiração dos espectadores. Presente no evento o escritor Louis Figuier (1862), relata:

No mês de Dezembro de 1844, às oito horas da noite, a praça da Concórdia estava repleta de curiosos, vindos de todos os pontos da capital, para assistir à experiência que os jornais tinham anunciado. Um espetáculo admirável deveria satisfazer cabalmente a sua curiosidade. Gerou-se em toda a multidão uma verdadeira estupefação. Ainda que houvesse um nevoeiro bastante intenso, a luz elétrica penetrava os vapores e inundava toda a praça da Concórdia. Constatei que se podia ler o jornal, junto do Obelisco, apesar da noite escura, que cobria o espaço não iluminado, e do nevoeiro que se espalhava por toda a parte. O aparelho de iluminação, isto é, as duas pontas de carvão entre os quais se formava o arco voltaico, estava colocado, do lado da rua Royal, sobre os joelhos da estátua da cidade de Lille, e cem elementos Bunsen estavam alojados num pequeno compartimento, fechado por uma porta de bronze, que se encontra no envasamento da estátua (FIGUIER, 1862:102).

$\mathrm{Na}$ mesma proporção que a experiência causou fascínio para alguns, por outro lado houve aqueles que criticaram a intensidade luminosa demasiadamente forte. "Uma luz como esta só deveria iluminar assassinatos, crimes públicos ou corredores de manicômios, um horror para realçar outro horror. Ao olharmos para ela uma única vez apaixonamo-nos pelo gás", declarações do escritor escocês Robert Louis Stevenson (STEVENSON apud COX, 1979:26) ao destacar o seu forte repúdio a luz voltaica como a "luz pesadelo". Outro problema que os cientistas enfrentaram foi com o desgaste dos eléctrodos e a instabilidade do arco, que tinha que ser manualmente ajustado. Com o objetivo de solucionar tal adversidade e obter a iluminação mais regular e contínua possível, vários estudiosos propuseram protótipos de reguladores automáticos, como Thomas Wright em 1846 e William Staite em 1848. No mesmo ano Foucault com ajuda de Duboscq, também inventor, aperfeiçoou e construiu o "regulador de Foucault", sistema semelhante ao de Staite. Todo o processo de investigação utilizando a lâmpada de arco como a base de estudo, foi sendo aprimorado ao longo dos anos. $\mathrm{O}$ fabrico de baterias mais baratas e geradores de indução mais práticos propiciaram a iluminação elétrica um futuro viável (BERNARDO, 2007:158). 


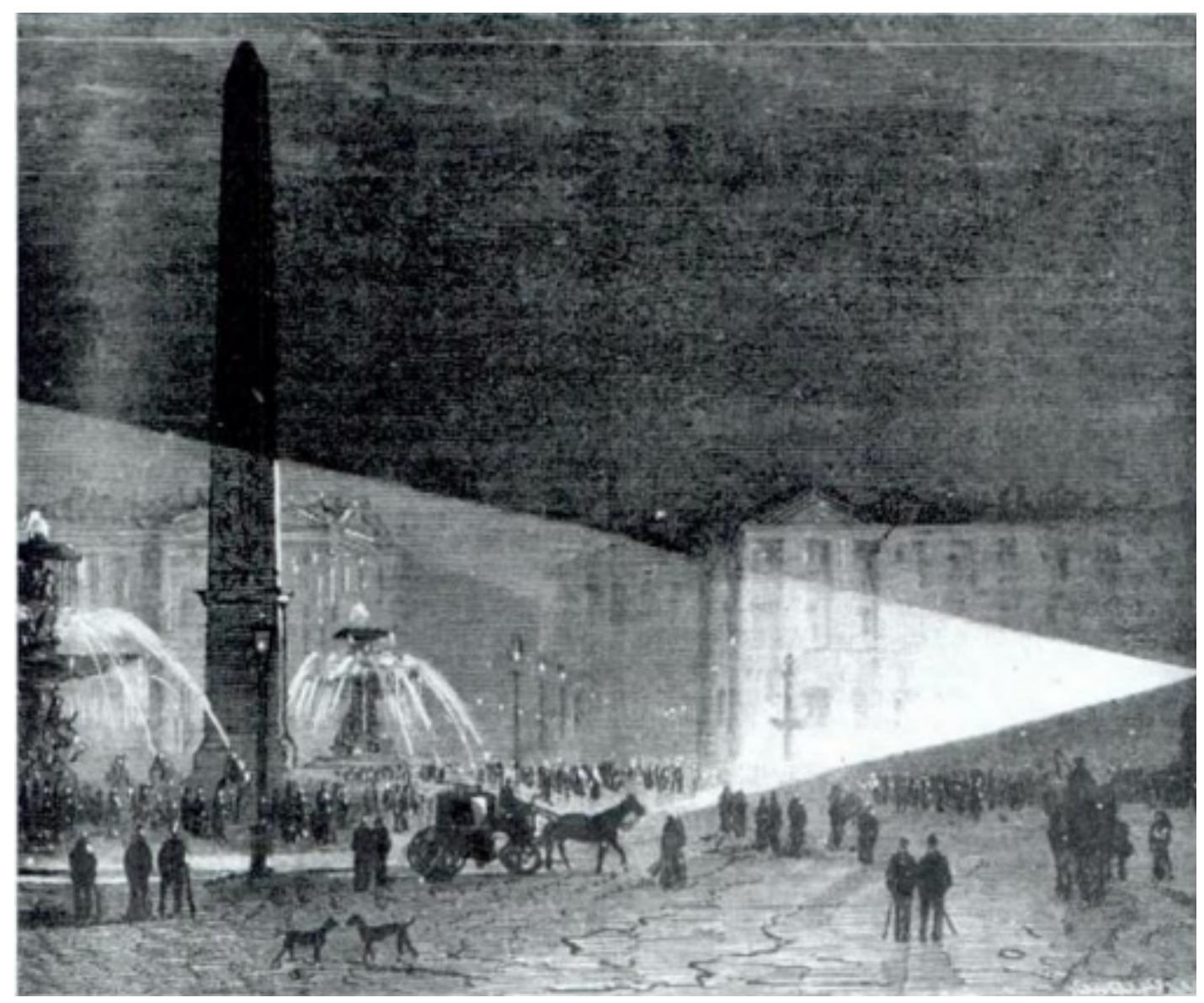

Figura 5 - Primeira experiência pública de iluminação elétrica na Praça da Concórdia, Paris. Fonte: https://books.google.com. br/books/about/Hist\%C3\%B3rias_da_Luz_e_das_Cores_volume_2.html?id=-YZL2h1jn8cC\&redir_esc= yhtml (2007)

E foi através dos projetos de Pavel Iablotchkov, engenheiro russo que em 1875 construiu as velas de Jablochkoff, uma versão do arco voltaico mais econômico que combinava barras dos eletrodos, posicionados lado a lado com distância de $3 \mathrm{~mm}$, separados por uma substância isolante denominada "colombin" e alimentados por geradores elétricos envoltos em um espaço fechado que dispensavam reguladores. Em vista disso a partir de 1878 as ruas de Paris, Londres e muitas outras cidades europeias, começaram a utilizar as velas de Jablochkoff na iluminação pública (PINTO, 2008).

De acordo com Abreu (2010), as primeiras lâmpadas incandescentes de filamento foram inventadas simultaneamente e independentemente pelo físico inglês Joseph Wilson Swan e pelo inventor americano Thomas Edison em 1778, inúmeras discussões foram desencadeadas sobre a prioridade da patente, entretanto a originalidade mantinha-se em dúvida posto que ambos montaram suas respectivas fábricas e laboratórios experimentais, para a confecção das lâmpadas em larga escala, no mesmo período. Apenas com a fusão das duas empresas pode-se cessar os conflitos em outubro de 1883. Assim nasceu a empresa inglesa Edison and Swan United Eletric Light Company Limited, que passou a ter licença de fabrico em vários países. Conjuntamente nesta época as lâmpadas começaram a ser difundidas no mercado, embora fossem de baixa intensidade luminosa. A novidade rapidamente passou a invadir pequenas salas residenciais e logo em seguida conquistou grandes espaços, como cafés, teatros, edifícios públicos, museus, palácios, hotéis, praças e ruas. A fim de poder alimentá-las, nestes locais foram instaladas 
máquinas geradoras de eletricidade, tornando a utilização mais prática e eficiente.

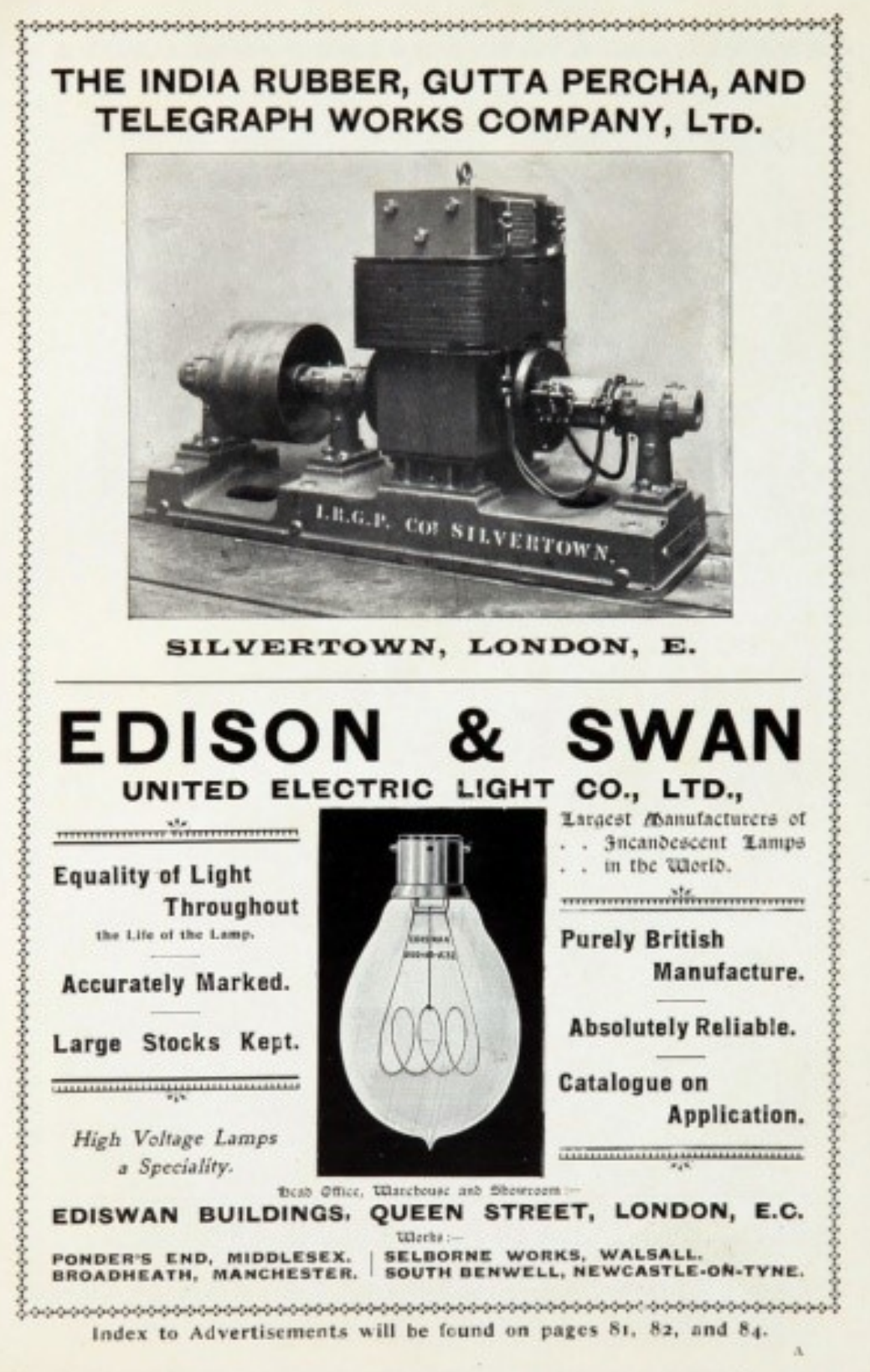
lâmpadas fabricadas pela compania de Edson e Swan em 1899. Fonte: http://www.gracesguide.co.uk/File:Im189908Cass-Edi.jpg (2015)

Além do que fora imaginado, as lâmpadas elétricas incandescentes sobrepujaram a função e alçaram o patamar de elemento decorativo. As "joias elétricas", como assim foram chamadas, referiam-se aos adornos luminosos que compunham as roupas e objetos cênicos nos teatros, pequenas lâmpadas de incandescência eram acionadas por engenhosas cápsulas de cristas e fios delgados conectados por uma pilha de zinco e carvão. Dos tablados para o exterior, as "joias elétricas" conquistaram espectadores e passaram a integrar comícios políticos e paradas comemorativas (ABREU, 2010).

No Brasil Edison conquistou a concessão da instalação por intervenção de Dom Pedro II, depois que o 
mesmo se encantou ao ver a luz elétrica na cidade de Filadélfia, Estados Unidos em 1876. Para cativar a população, o imperador, inaugurou a nova iluminação junto a Estação da Estrada de Ferro D. Pedro II, atual Estrada de Ferro Central do Brasil, na cidade do Rio de Janeiro em 1879. Dois anos depois, em 1881, começaram as substituições por toda a cidade, da iluminação a gás pela elétrica. No mesmo ano o Jardim do Campo da Aclamação, hoje Praça da República, recebeu 16 lâmpadas em seu primeiro trecho, acionadas por máquinas a vapor, juntamente o edifício do Ministério da Aviação ganhou 60 lâmpadas da Edison Electric Co. Contudo, na cidade de Campos do Goytacazes, estado do Rio de Janeiro, foi inaugurado o primeiro serviço de iluminação pública municipal da América do Sul, pioneira com 39 lâmpadas movidas a um pequeno motor a vapor com 3 dínamos (ESTEVES, 2010).

A virada do século XX permitiu que mais empresas estrangeiras investissem no Brasil. A exemplo da empresa canadense Light, que investiu nos estados do Rio de Janeiro e São Paulo, com postes elegantes que proporcionaram aos locais, sofisticação e modernização. Por 30 anos o foco era expandir para todo o país, que diferente dos dias atuais, erguia-se primeiro a infraestrutura e depois estabelecia o desenvolvimento urbano. A luz elétrica foi um desenvolvedor social e comercial para lugares remotos do país (BICALHO, 2009).

Mesmo com grandes avanços tecnológicos os inventores não se davam por satisfeitos com a qualidade da composição das lâmpadas, desejavam que a luz artificial ideal dispusesse de longa duração e elevado rendimento. Pesquisas foram realizadas, materiais metálicos foram testados, e somente 1906 o bemsucedido filamento de tungstênio incorporou as lâmpadas incandescentes por intermédio de Hans Kuzel, químico austríaco, que descobriu a luz com mais 700 horas de vida. No final do século XVIII foram iniciadas novas etapas de pesquisas, depois de vislumbrar o que os metais poderiam fazer, os pesquisadores queriam testar a eficiência dos gases. Desde a experiência de Davy em 1802, já havia relatos de experimentos eletrostáticos com gases contidos em globos que produziam faíscas de luz. Alexandre Edmond Becquerel, em 1857, obteve pela primeira vez uma lâmpada fluorescente a partir de um tubo de descarga Geissler recoberto de material fluorescente. A evolução das lâmpadas fluorescentes necessitou longos anos de aprimoramento até as atuais que conhecemos. Somente em 1930 foram apresentadas ao público na Feira Mundial de Nova Iorque, e sua comercialização após 8 anos. Ordinariamente elegida como lâmpada de luz fria, permitiu que o século XX a popularizasse tornando-a essencial em muitas aplicações (BERNARDO, 2007:187).

O arquiteto e urbanista francês naturalizado brasileiro, Lúcio Costa, aplicou na cidade satélite Brasília na década de 1950, luminárias que utilizavam fluorescentes, montadas e projetadas de acordo com os princípios modernos da luminotécnica. Desde a criação da lâmpada de arco voltaico, o universo da iluminação passou por infinitas transformações, surgiram lâmpadas de vapor de mercúrio, vapor de sódio, lâmpadas de indução, alta e baixa pressão e tantos outros modelos com diferentes funções. Ingressando para os anos de 1960, as lâmpadas de vapor de sódio a alta pressão e a multivapores metálicos, surgem para configurar a paisagem urbana das cidades no Brasil e exterior. Estas lâmpadas foram amplamente utilizadas por oferecerem acessibilidade e economia viável para as ruas e espaços urbanos (SILVA, 2006).

Apesar do longo processo de desenvolvimento das lâmpadas que iluminaram a história, o que pudemos aprender com o passado é que não há limites para o conhecimento e aperfeiçoamento das tecnologias. Ontem só havia a preocupação com a durabilidade e quantidade de emissão de luz, hoje, o mundo reivindica por mais eficiência na reprodução de cores e sustentabilidade. Não há mais espaço para 
luminárias com grandes gastos energéticos. O que julgamos ser o futuro há mais de 30 anos atrás se tornou o presente do cotidiano da sociedade. O Light Emitting Diodo, conhecido como LED, foi a descoberta de Henry Joseph Round em 1902, que proporciona o novo leque de pesquisas da contemporaneidade.

Segundo Farley (2014), Round realizou experimentos com tensão elétrica sobre diodos, que são semicondutores construídos através da combinação de elementos como índio, arsênio, gálio, fósforo, germânio, silício, alumínio, nitrogênio e carbono. Ao observa as reações dos ensaios em diferentes voltagens, notou que alguns diodos emitiam um brilho único acima da superfície do material, este fenômeno era causado pela eletricidade que atravessava a substância convertendo-a em luz. Todavia o cientista não deu importância significativa a descoberta e somente em 1962, por intermédio do estadunidense Nick Holoniack Jr. que reassumiu os estudos em eletroluminescência, pode-se concretizar a criação da primeira lâmpada de LED na cor vermelho, posteriormente surgiram na cor amarelo e verde.

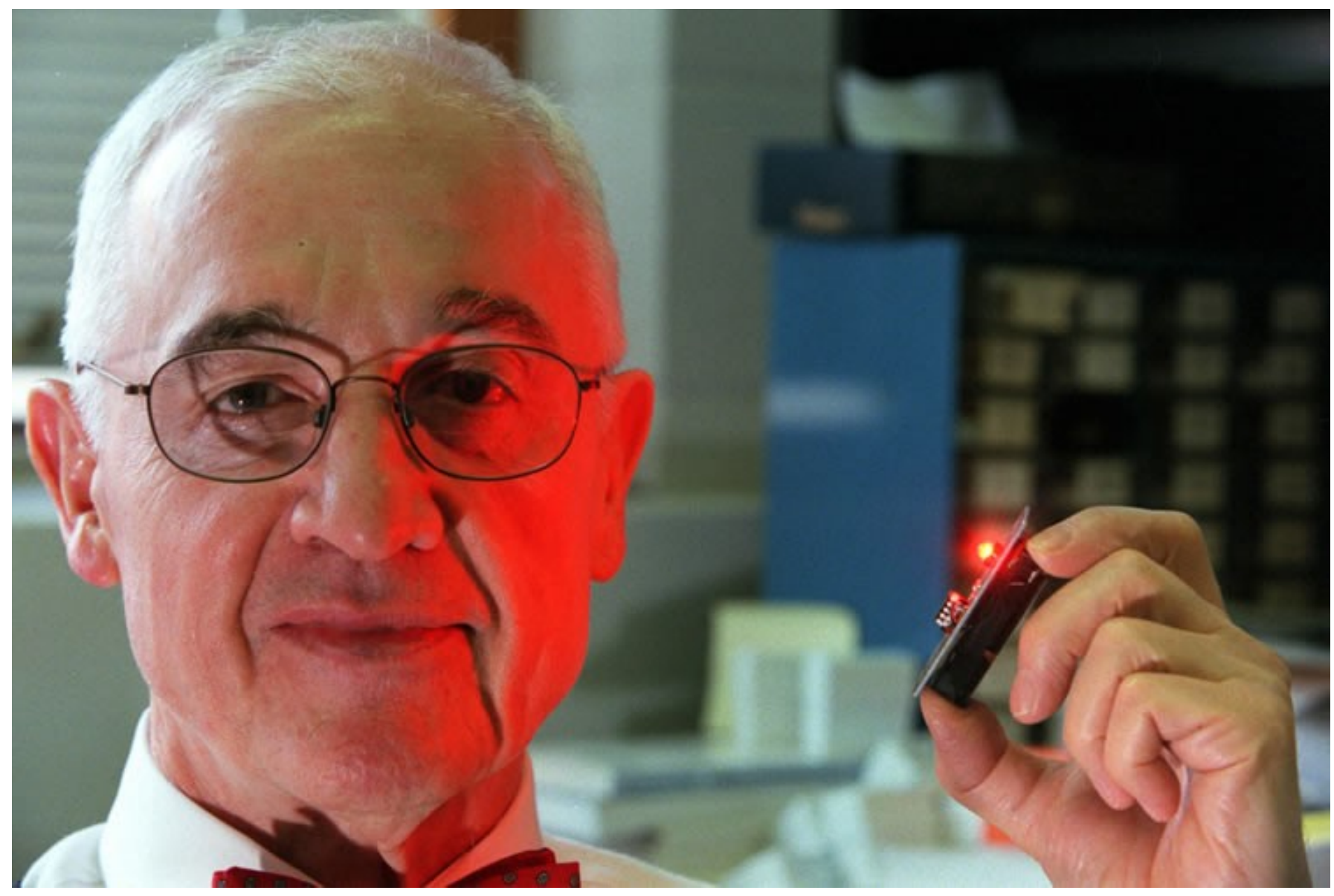

Figura 7 - Cientista Nick Holoniack Jr. com sua criação, o LED vermelho. Fonte: http://news.illinois.edu/ii/12/1018/LED_at_50_Nick_Holonyal_Jr.html (2010)

Até aquele momento os avanços sinalizavam resultados promissores, mas uma das maiores conquistas no campo apenas chegou com a década de 90, com o desenvolvimento do LED na cor azul. Shuji Nakamura foi o engenheiro japonês responsável por essa consecução. Como consequência foi possível unir as três cores básicas: vermelho, verde e azul, gerando o LED branco, que hodiernamente é amplamente reproduzido em diversas tecnologias como fonte de luz. 
Por fim, o Light Emitting Diodo já é uma realidade, que vem assumindo gradativamente o papel de protagonista no cotidiano das pessoas e cidades. Conferindo a arquitetura edificante e urbana, economia, qualidade, segurança e entretenimento. A luz artificial formata os eventos sociais, acendendo nas ruas a identidade noturna. Uma expressão concebida pela publicidade, artistas, comércio, transeuntes e o simples movimento dos veículos.

\section{A Luz noturna e a psicologia comportamental urbana}

"A ideia tradicional da iluminação urbana sustentável é baseada apenas na economia e aparência técnica ambiental. Porque a iluminação é principalmente para pessoas. A iluminação urbana deveria ser focada nas experiências humanas com qualidade social e responsabilidade envolvida" (ROSSO, 2012).

A História prova que a humanidade construiu grandes feitos diante da ausência do sol. Fazendo-se instrumento de cidadania e combate a criminalidade, a iluminação pública distingue, inibe e guia a paisagem urbana. Contudo, a vivência noturna atual revela ser um recurso insuficiente e mal aproveitado, no qual é banalmente configurado para exercer unicamente o emprego estático de iluminar.

É fato que houve progresso na condução dos atendimentos às demandas sociais, todavia pouco se evoluiu para a luz multifuncional do panorama urbano, que poderia projetar sensorialismo, ocupar sítios públicos abandonados, promover cultura, mais renda e coibir efetivamente a violência. Infelizmente a realidade política de muitas metrópoles brasileiras e estrangeiras, destacam cenários noturnos repetitivos e equivocadamente aplicados, com padronização e multiplicação de postes inexpressivos que conotam ambiência monotona e pouco atrativa. A vigente realidade da vida moderna é a população ativa por 24 horas, onde há dois mundos que ocupam o mesmo espaço geográfico, mas que constituem perspectivas distintas. Fronteiras marcadas pelo ar, em que um começa quando o outro se apaga.

Existe uma quantidade considerável de vida noturna emergente que possui identidade e habitantes próprios. Empresas locadas em países como China e Reino Unido, já compreendem que essas novas atividades e trabalhos noturnos produzem uma próspera economia. Perante a isso, Lam (2015) define:

Em 2009, a economia noturna britânica foi estimada a gerar $27 \%$ do total, enquanto Sydney conseguiu criar \$2,7 bilhões de benefícios econômicos com apenas \$127 milhões de gastos com a noite. Quando projetamos para a noite, precisamos considerar a necessidade das ruas e lugares para permitir um complexo de usos econômicos e sociais, e vêem a iluminação como o facilitador da florescente economia urbana. (LAM, 2015:14).

A cidade contemporânea é um corpo nutrido por seus habitantes que dispõem de linguagem própria, estruturada de sensações e gestos, interligando o meio físico às pessoas. Por estarem em ritmo de crescimento rápido devem ser analisadas por seus diferentes contextos, tendo como exemplo: a situação climática, demográfica e geográfica. A comunidade é fundamental na contribuição de espaços mais usuais e interativos, e à medida que novas tecnologias são ofertadas ao setor de consumo privado, presumi-se que haja aumento de solicitações por ambientes públicos mais cômodos que abracem todos os tipos de grupos sociais e que promovam experiências perceptuais para os usuários. Conforme explica a escritora e socióloga Lofland (1998), a qualidade de vida das grandes cidades europeias está associada ao diálogo entre as prefeituras e moradores, ao manter todas as propostas urbanísticas dentro do domínio público. Outro fator apresentado pela autora é a respeito da opinião pública como condição favorável para a 
economia, uma vez que ajuda a trazer investimentos do setor privado, que vão até $40 \%$ do valor gasto.

A percepção provocada por uma boa iluminação pública cria significados de cultura para a cidade, como elemento importante do design. É a expressão do novo gênero de arte moderna capaz de redefinir os espaços e a energia sentida. A maneira que os elementos luminosos são inseridos no ambiente físico, a simbologia e o psicológico são trabalhados, podendo interferir na atmosfera e clima criando ligações dos símbolos a imagem do local. "Estes signos luminosos, abstratos ou significativos, podem explicitar um espaço, como marcos luminosos ao longo do contorno de uma praça, exprimir trajetórias gráficas, perspectivas importantes, percursos reais, imaginários ou poéticos" (MIGUEZ, 2005:06), e proporcionar a visualização de algumas das tramas que constroem a malha urbana, como as vias, os canais, as linhas de ônibus, trem ou metrô, entre outros.

Quando o imaginário é explorado por cenografias animadas, a harmonia da luz, cores e sons combinam-se e transportam os observadores para lúdico, ao conectar a atração com as emoções primárias de alegria e surpresa, vislumbrando a atmosfera fabricada. A título de exemplo, os trabalhos realizados em Video Mapping (Mapeamento de vídeo), que são técnicas de animação cinematográficas, videográficas ou computacionadas em superfícies internas e externas que unem o mapeamento da estrutura física do edifício junto aos efeitos tridimensionais projetados com finalidade de sobrepor somente na área desejada da construção, presenteando o espectador com entretenimento audiovisual (GARCIA, 2014).

O impacto cognitivo da luz à noite, influencia nas alterações comportamentais e de humor, que são determinadas pela qualidade do meio. Se estiver preenchido por significados positivos, a área irá atrair o visitante há passar mais tempo, caso contrário ocasionará reações opostas e toda a concepção servirá para repelir. Esses comportamentos devem ser identificados por estudos preliminares para que possam responder os valores necessários que agregam a relação pessoa-ambiente (VARGAS, 2011).

Cidades que mesclam arquitetura antiga com a contemporânea representam aos residentes um vínculo de gerações com o patrimônio. Planos que valorizam a luz como instrumento que destaca as estruturas dos edifícios, facilita a compreensão da relevância histórica, permitindo que a noite seja uma tela pintada por camadas luminosas que contam a passagem do tempo. 


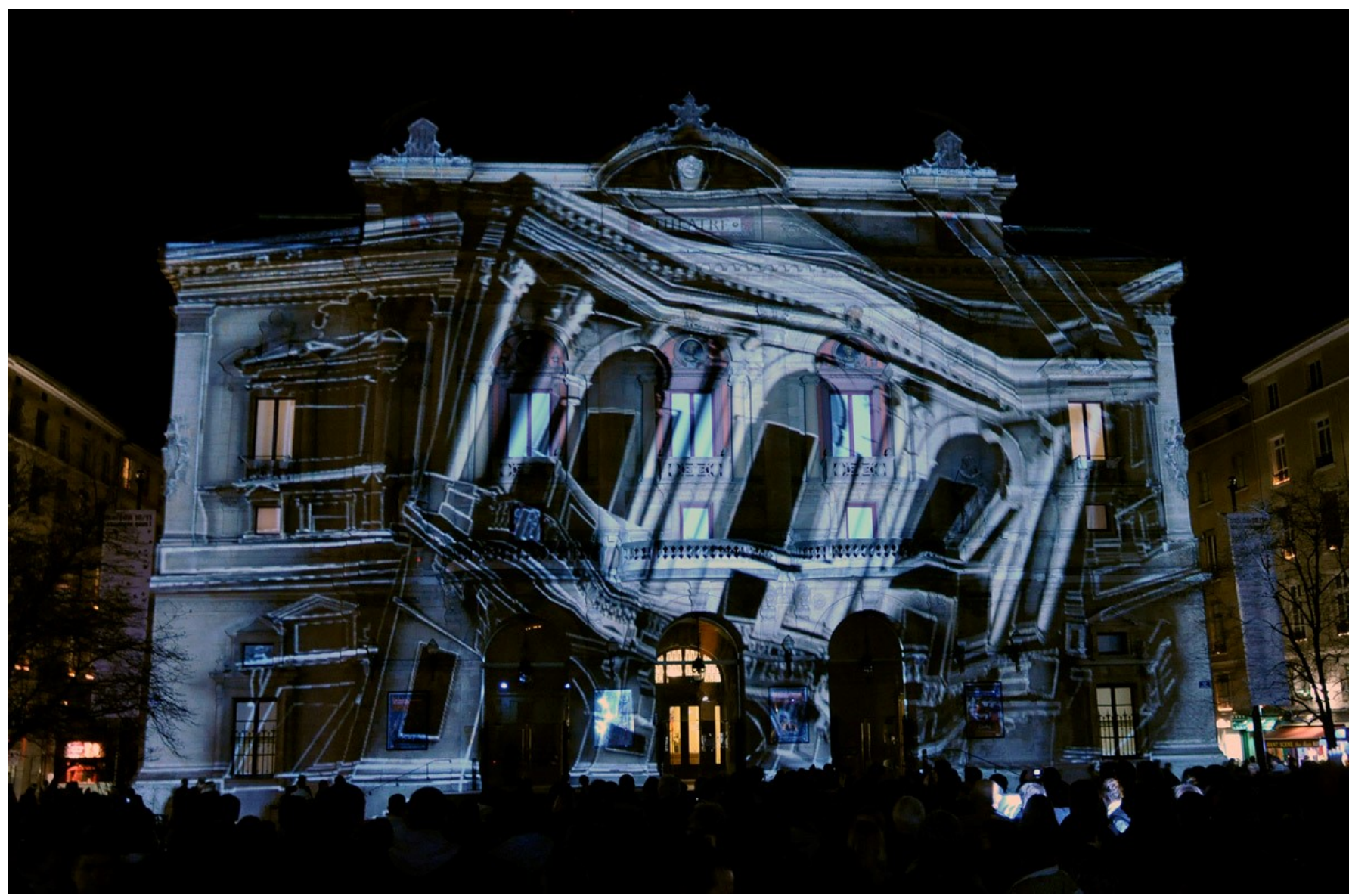

Figura 8 - Demonstração de Video Mapping. Fonte: http://www.tracksevenevents.com/blog/-projectionmapping-the-new-power-in-event-management (2015)

Não obstante, instalações temporárias também são fontes de interação comunitária. A arte produzida em eventos, como festivais de luz, trazem pessoas e fomentam a promoção da cidade e de atividades comerciais. Como é o caso dos tradicionais festivais de flor de cerejeira do Japão. Que atraem em média, durante 10 dias, 20 mil pessoas. O espetáculo a céu aberto dispõe de iluminação em cada árvore, enfatizando o significado das flores e a importância da identidade cultural do país. No castelo de Fukuoka, mais de mil árvores de cerejeira são iluminadas para projetar a sombra nas paredes da fortaleza. São eventos como estes que encantam os japoneses e turistas, oferecendo a todos uma experiência distinta e inigualável (K, 2016). 


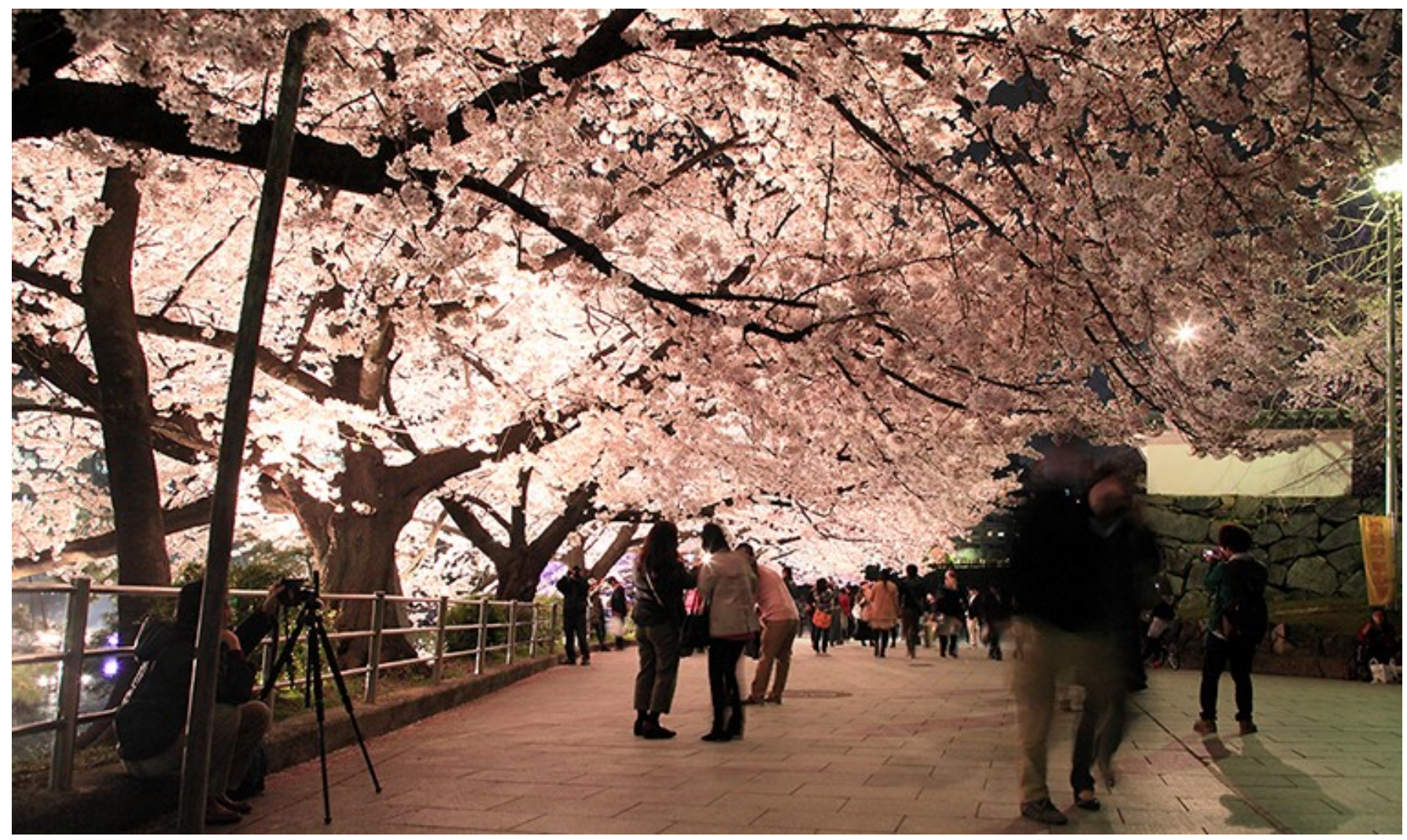

Figura 9 - Árvores Iluminadas do castelo de Fukuoka. Fonte: http://saku-hana.jp/gallery/gallery.html (2015)

\section{4. $O$ excesso e a linguagem inclusiva}

A saúde social noturna também pode ser verificada pelo excesso de informação. A poluição luminosa é um dos problemas salientados pela população que mora nos grandes centros. Letreiros publicitários, equipamentos irregulares, temperatura de cor inadequada, ofuscamento e luz intrusa, são alguns dos problemas mais frequentes. Isso ocorre por haver diversas fontes de luz que geram verdadeira redundância entre luz pública e privada. Conforme fora visto anteriormente, toda iluminação acarreta reações físicas e comportamentais no corpo humano, o uso incorreto pode causar impactos negativos e permanentes na qualidade de vida, como: depressão, ansiedade, insônia, enxaqueca e sensibilidade ocular. Estudos revelam que haverá um crescimento de $6 \%$ ao ano na iluminação noturna e em áreas como Tóquio e México chegará a 20\%, o que contribui também para desperdícios de energia e aumento de emissão de gás carbono na atmosfera (LAM, 2015).

Além das emissões excessivas devem-se ficar atento às demais condições sociais, como o envelhecimento populacional. Este fenômeno está ocorrendo em escala global e principalmente em países desenvolvidos. O Brasil é atualmente classificado com uma população adulta e estimasse que em futuro breve tenha o quadro demográfico envelhecido. Para os idosos existe uma maior sensibilidade às fontes de luz. Isso se deve as alterações dos índices de refração e coloração, isto é, a pessoa passa a enxergar em cores mais amareladas. Aos 70 anos é fundamental ter fontes de luminosas menos ofuscantes e que produzam mais luminância. Ambientes que possuem condições luminotécnicas voltadas para a juventude, tendem a despertar estresse para aqueles que estão na terceira idade. "A inclusão de tais considerações nos projetos luminotécnicos de espaços públicos de convivência com grande concentração de idosos, como parques e 
praças, favorece positivamente a consolidação de ambiências noturnas" (CARVALHO; MARTINS; VANDERLEI, 2008:06).

A cor é outro fator indispensável para promover espaços abertos de qualidade sem interferir na vizinhança. A universidade de Cambridge, Massachusetts, desenvolveu a primeira iluminação pública baseada nos ciclos circadianos. No que se refere a ser um sistema que adapta os comprimentos de onda e os espectros de cor, de acordo com o lugar, tempo e tarefa exercida. Nas ruas são controlados através de sistema wireless, que podem regular a intensidade, cor gradativa e trabalhar em modo econômico (LOCKLEY; LIPSON, 2014).

\section{A iluminação como ferramenta urbanística}

Ao reconhecer que as experiências humandas e a diversidade cultural são parte da força motriz de um bom projeto de iluminação pública, serão apresentadas três propostas distintas que tiveram sucesso na interação do espaço com o público. Com um espetáculo urbano interativo os projetos foram escolhidos por respeitarem todo o processo, levando em consideração a localidade, inclusão, pretensões e a legislação vigente do local.

O primeiro é o projeto Swing Time (Tempo do Balanço), localizado em Boston, Estados Unidos, de design assinado por Höweler e Yoon Architecture, que foi montado para servir de playground para todas as idades. Instalado entre um centro de convenções e o centro de exposições, o parque tem como objetivo ativar o espaço livre utilizando de tecnologia e criatividade. O balanço é composto por vinte formas circulares de polipropileno, que possuem três tamanhos para acolher todas as estaturas, soldados em uma estrutura de aço. Seu conteúdo é composto por lâmpadas de LED que ao serem ativadas oscilam nas tonalidades de cor branco, azul e roxo, à medida que a velocidade e o tipo de movimento são realizados. As peças foram projetadas para incentivar o setor tecnológico que está em expansão na região e ao mesmo tempo servir como entreterimento para as famílias da localidade. A colaboração da prefeitura e o envolvimento da comunidade foram primordiais para o sucesso. O Swing Time é o laboratório de idéias que tornou-se palco de inúmeros eventos sociais e culinários para a comunidade (MACLEOD, 2014). 
Revista Científica Multidisciplinar Núcleo do Conhecimento - RC: 16496 - ISSN: 2448-0959

https://www.nucleodoconhecimento.com.br/arquitetura/luz-como-intervencao

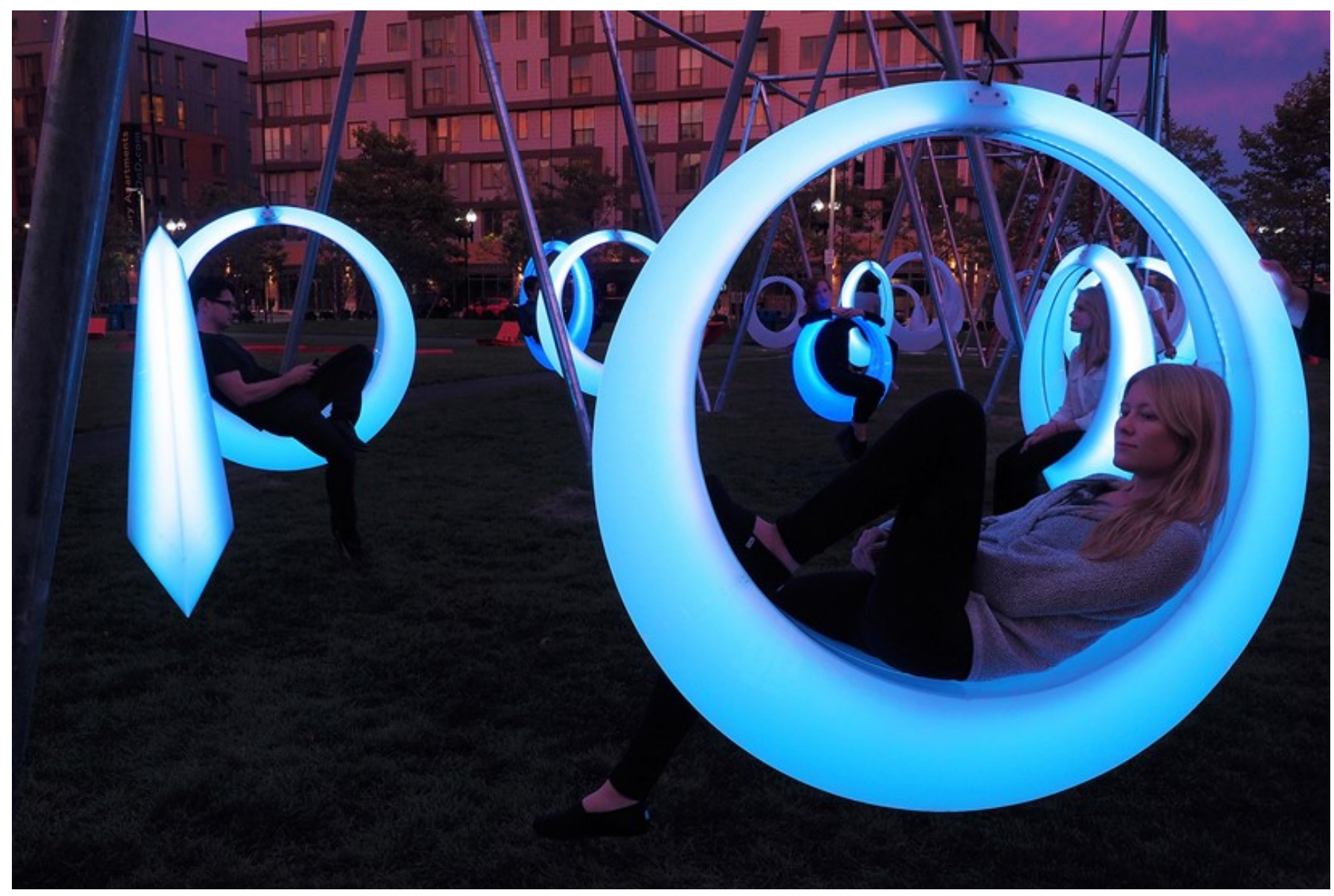

Figura 10 - Equipamento urbano Swing Time ao entardecer. Fonte: John Horner (2016) 


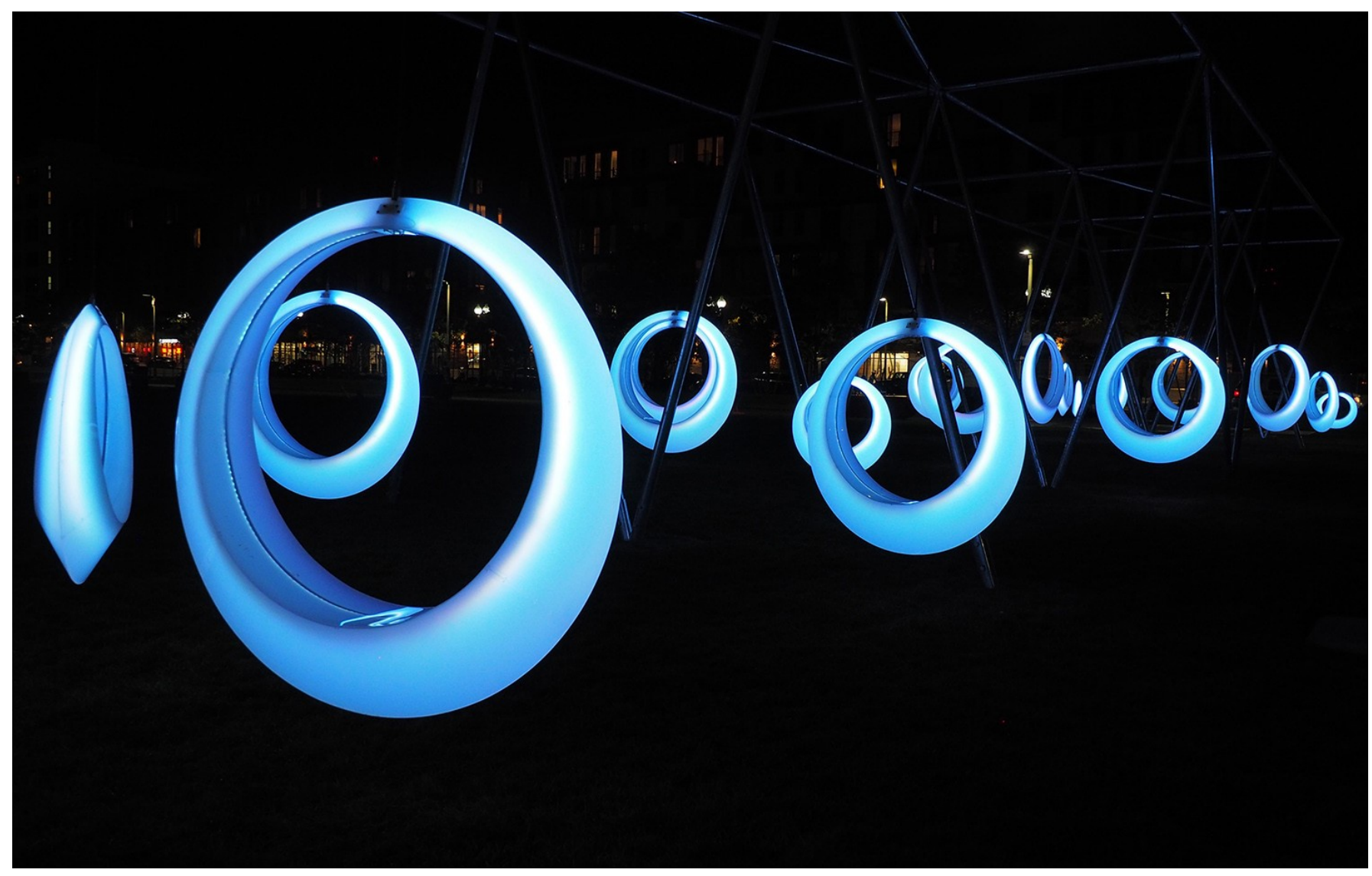

Figura 11 - Equipamento urbano Swing Time de noite. Fonte: John Horner (2016)

O segundo é a instalação Marling, fixada na praça central da cidade de Eindhoven na Holanda, é considerado a aurora boreal tridimensional das vozes. Projetado pelo grupo Usman Haque, os efeitos permitem que milhares de pessoas participem de uma experiência única onde os espectadores tornam-se atores da cena urbana. No projeto são utilizados vários projetores $2 \mathrm{D}$ a laser, microfones e máquinas de fumaça, que por via da interação dos sons do público, criam padrões de linhas simples que ao serem incorporados geram infinitos fenômenos em 3D. O movimento que a luz aparente atua sobre a soma audiovisual, explora a inventividade em cores animadas que pairam em torno da multidão. Um trabalho que conduz os participantes a um espaço virtual urbano originado pelas mudanças de volume e sons (LI, 2015). 


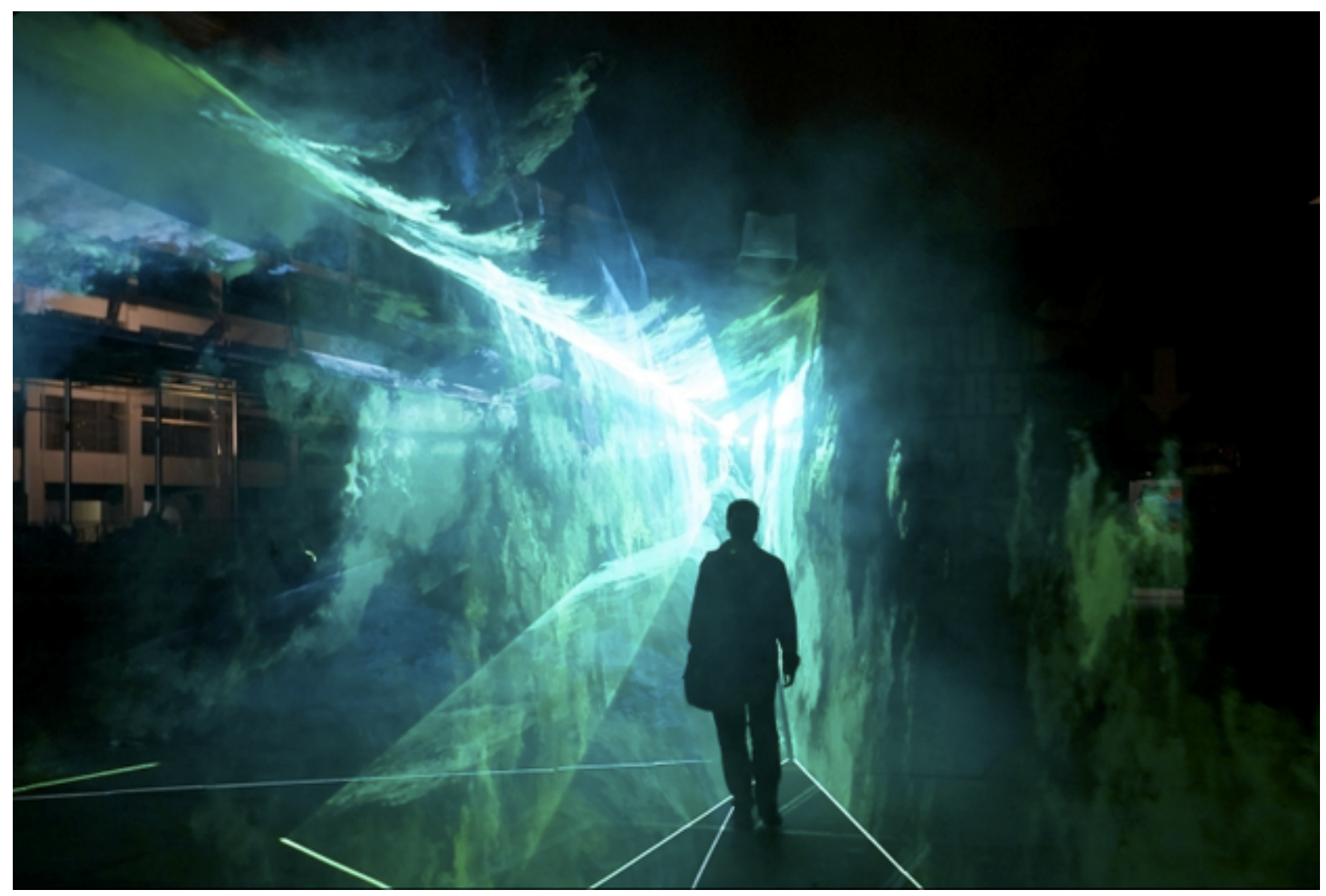

Figura 12 - Instalação Marling. Fonte: http://www.haque.co.uk/marling.php (2012)

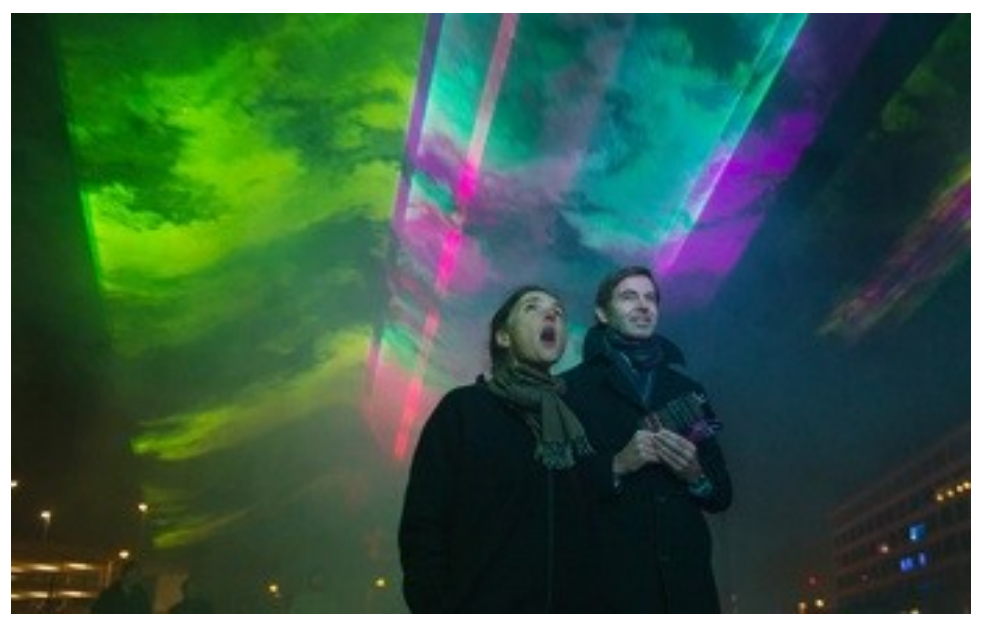

Figura 13 - Instalação Marling, a voz dos transeuntes mudam a cor e o formado dos desenhos no céu. Fonte: http://www.haque.co.uk/marling.php (2012)

E por último será apresentado o projeto de revitalização da Praça Leicester em Londres, Inglaterra. O trabalho de design de iluminação foi realizado pelas empresas Burns \& Nice, Arup Lighting e Hyder Consulting. Inicialmente a prefeitura londrina tinha como objetivo melhorar a sensação de segurança da praça, iluminando as áreas pavimentadas e salientando os monumentos e esculturas dos jardins, que não tinham boa visualização nos sistemas de vigilância à noite. Ao perceberem um grande potencial 
impactante, os arquitetos e designers desenharam postes menores que favoreceram os acessos do local, iluminando-os por completo e sem ofuscar os motoristas que trafegam no entorno. Uma série de projetores de LED 12 watts com luz morna em formato de colunas sob medida, foram implantados em grupos dentro dos limites da praça. Dessa forma com contornos sutis as luminárias não entraram em conflito com o cenário natural durante o dia. Além disto, grupos de painéis de policarbonato transparente com LED, foram adequados em várias alturas formando um conjunto ópito ajustável. Estrategicamente posicionados, os pontos de luz no chão atribuirão volume e contornos aos elementos verticais, controlados por sistema remoto e dimerizável de acordo com a estação do ano e a passagem da noite para o dia. Juntamente, luzes horizontais foram colocadas abaixo dos bancos de concreto que compõe o mobiliário urbano, para que o passeio fosse inteiramente iluminado evitando acidentes. Um spot de cada poste foi redirecionado para iluminar as copas das árvores, assim estimulou uma paisagem romântica. Este é um projeto simples, mas que liberou o potencial noturno contido para a cidade e a maneira que as pessoas usufruem dela (IGUZZINI, 2015). 


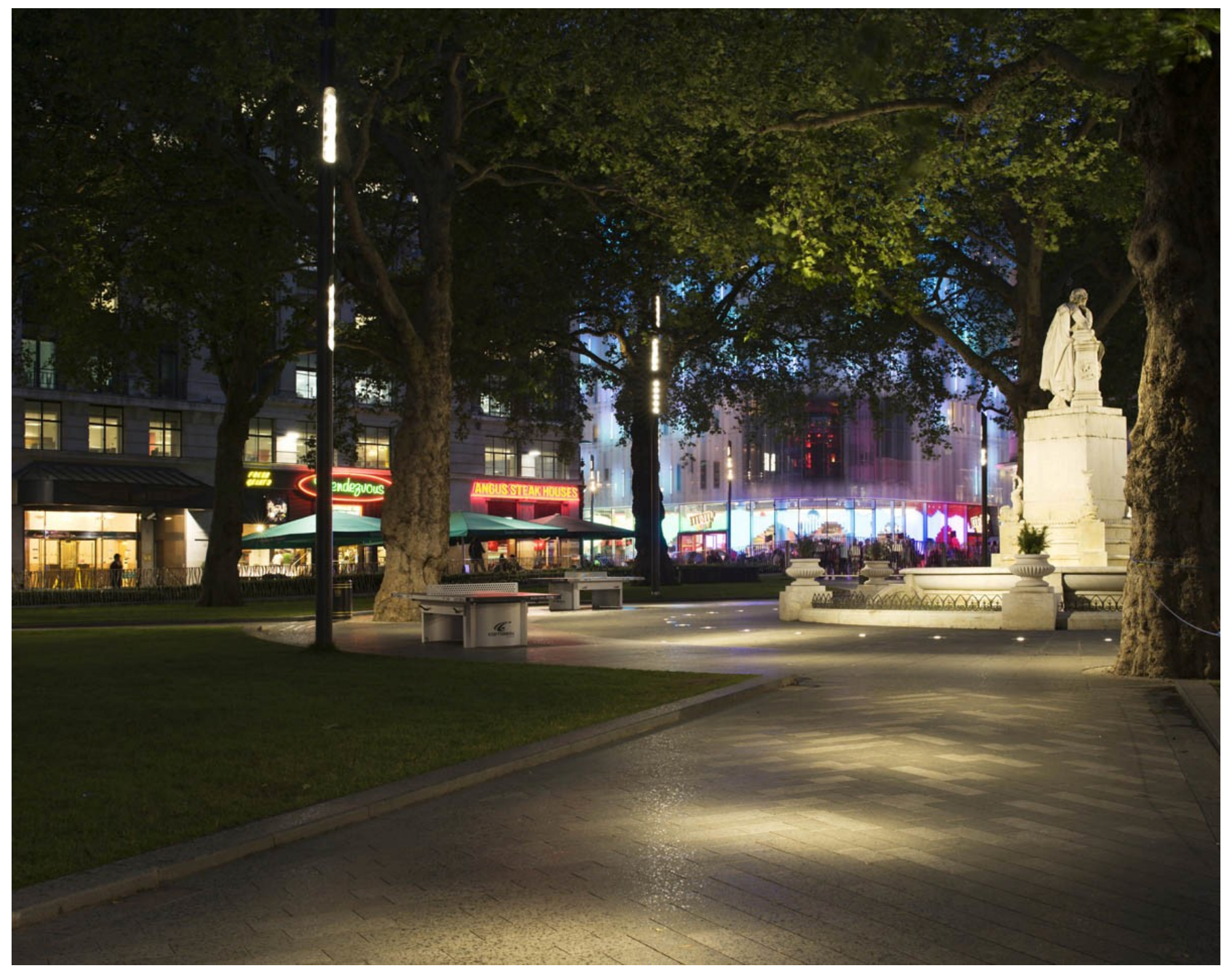

Figura 14 - Passeio da Praça Leicester em Londres. Fonte: http://www.haque.co.uk/marling.php (2016) 


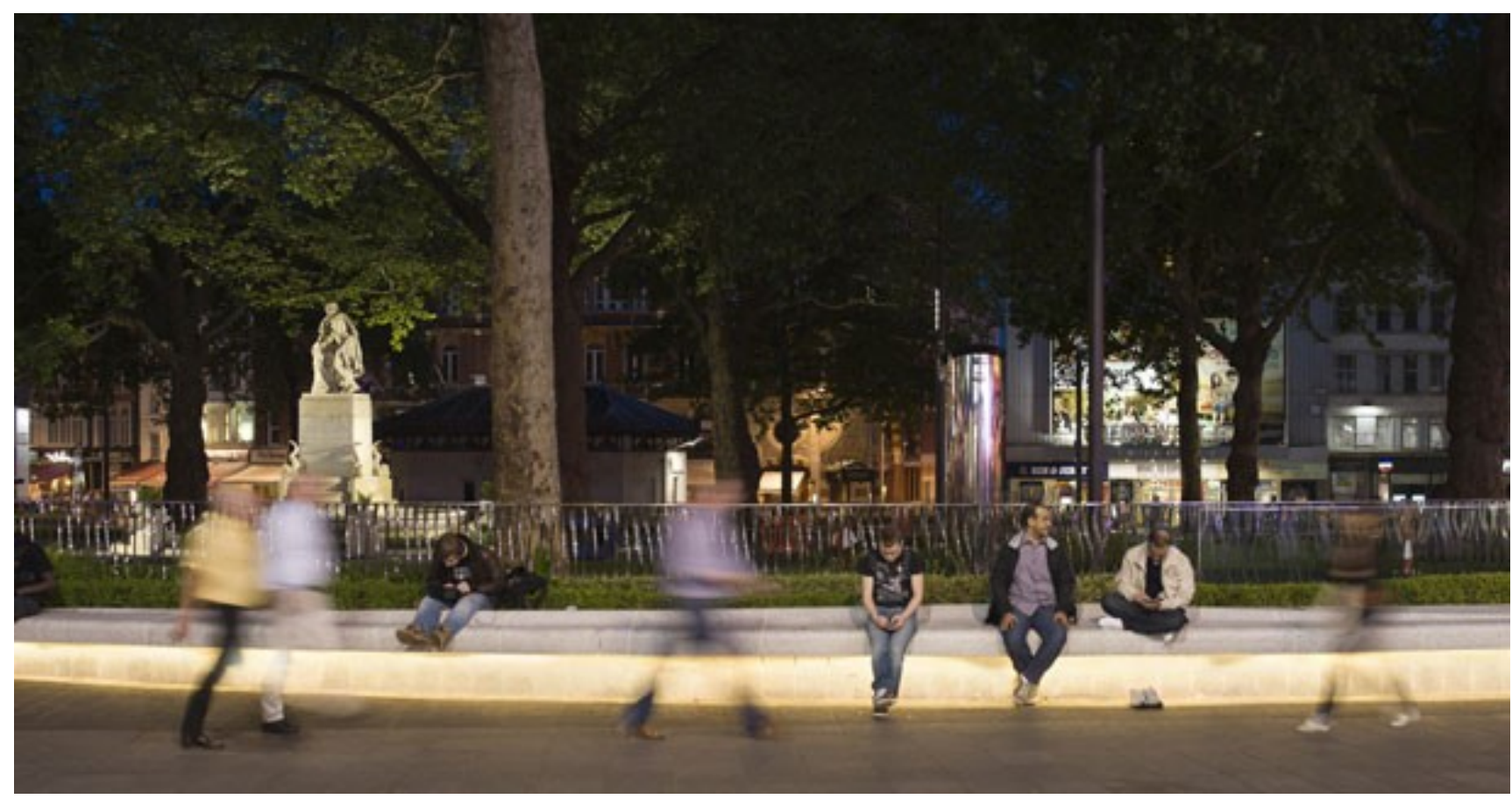

Figura $15-$ Banco sendo iluminado horizontalmente com luz difusa. Fonte: http://www.haque.co.uk/marling.php (2016)

\section{Conclusão}

A noite é tão importante quanto o dia. Pensamentos mais inteligentes sobre a iluminação pública proporcionam condições mais favoráveis nas inter-relações pessoais e a maneira que a rua é vista e julgada. A carência de planejamentos estratégicos voltados ao design noturno representa os problemas sociais e políticos que a população enfrenta diariamente. Não necessariamente, devem ser realizadas grandes intervenções urbanísticas, quando há dedicação e criatividade, a mente é a conexão capaz de levar a lugares extraordinários sem gastos orçamentários exorbitantes.

A lâmpada é o meio pelo qual as pessoas e a arquitetura tornam-se protagonistas do desenho da cidade, extraindo os melhores resultados que prosperam pela conectividade que somente a noite pode presentear. O futuro é cada vez moldado pelas experiências, com foco nas soluções e contextos específicos do comportamento urbano, para transformar ambientes mais agradáveis e seguros.

No passado havia a insistência de que mais luz era sinônimo de qualidade. Mas a abundância de muitas áreas urbanas trouxeram consequências negativas. É preciso entender as diferentes tonalidades da noite para que se criem abordagens eficazes.

O sucesso de projetos específicos depende, em muitos casos, da compreensão e uso adequado das tecnologias. Os benefícios somente serão sentidos por aqueles que trabalham com economia e o ambiente. A luz é fundamental para toda a vida social, mas a iluminação é o conceito de interação entre a humanidade com a cidade 24 horas.

\section{Referências}


ABREU, Yolanda Vieira de. Energia Sociedade e Meio Ambiente. Brasil: Eumed, 2010.

BERNARDO, Lúis Miguel. História da Luz e das Cores. Porto: Up, 2007.

BICALHO, Ronaldo. A energia elétrica no Brasil I: a introdução da eletricidade no país. Rio de Janeiro: Artigo, 2009. Disponível em: <http://blogln.ning.com/profiles/blogs/a-energia-eletrica-no-brasili>. Acesso em: 20 de setembro de 2016.

CARVALHO, Ladjane Barros de; MARTINS, Laura Bezerra e VANDERLEI, Luiz Onélio de Oliveira. Lighting Design e Ergonomia da Luz Artificial: O Impacto da Iluminação Pública Sobre a Cidade e Seus Usuários, Olinda, 2008. Disponível em: <http://www.cgti.org.br/publicacoes/2016/01/18/lightingdesign-e-ergonomia-da-luz-artificial-o-impacto-da-iluminacao-publica-sobre-a-cidade-e-seus-usuarios/> . Acesso em: 6 de novembro de 2016.

COX, A. James. A Century of Light. Nova Iorque: Benjamon Company/Rutledge Book, 1979.

DERZER, Farley. Cidade à noite: iluminação artificial e modernidade. Brasília: Universidade de Brasília, 2014.

ESTEVES, Adam. Como surgiu a iluminação pública. Londrina: Universidade Estadual de Londrina, 2010.

FIGUIER, Louis. Spectroscopes et analyse spectrale. Paris: Livraria Hachette et Cie ,1862. Disponível em: <http://gallica.bnf.fr/ark:/12148/bpt6k73257/f8.image>. Acesso em: 16 de setembro de 2016.

GARCIA, Rafael de Oliveira. VIDEO MAPPING: Um estudo teórico e prático sobre projeção mapeada, Bauru/SP: Universidade Estadual Paulista, 2014. Disponível em: <http://repositorio.unesp.br/bitstream/handle/11449/119214/000747199.pdf?sequence=1>. Acesso em: 6 de novembro de 2016.

IGUZZINI, Illuminazione. Leicester Square, Itália, 2015. Disponível em: <http://www.iguzzini.com/projects/project-gallery/leicester-square/>. Acesso em: 6 de novembro de 2016.

K, K. Fukuoka Castle Sakura Festival 2016 (Japan), Japão, 2016. Disponível em: <http://endlesstravelingmap.blogspot.com.br/2016/04/travel-fukuoka-castle-sakura-festival.html>Acesso em: 6 de novembro de 2016.

LAM, Florence. Cities Alive - Rethinking the Shades of Night. London: ARUP, 2015.

LI, Renxiang. Visual Motion Perception in Projected Space, China, 2015. Disponível em: <http://www.interactivearchitecture.org/visual-motion-perception-in-projected-space.html>. Acesso em: 6 de novembro de 2016.

LOCKLEY, Steven e LIPSON, Sam. Cambridge Streetlight Conversion Fact Sheet, Cambridge, 2014. 
Disponível em: <http://www.cambridgema.gov/ /media/Files/electricaldepartment/LED\%20Conversion $\% 20$ Fact\%20Sheet_FINAL.ashx>. Acesso em: 6 de novembro de 2016.

LOFLAND, Lyn H. The Public Realm - Exploring the City's Quintessential Social Territory. New Jersey: New $\quad$ Brunswick, $1998 . \quad$ Disponível em: <https://books.google.com.br/books/about/The_Public_Realm.html?id=vckzR8aHfJIC\&redir_esc=y>. Acesso em: 5 de novembro de 2016.

MACLEOD, Finn. Get Swinging in Boston on these Glowing LED Hoops, Boston, 2014. Disponível em: <http://www.archdaily.com/549643/get-swinging-in-boston-on-these-glowing-led-hoops/>. Acesso em: 6 de novembro de 2016.

MARTINS, Juliana. O papel social da luz urbana. Edição 69, Outubro de 2011. Disponível em <http://www.osetoreletrico.com.br>. Acesso em: 15 de setembro de 2016.

MIGUEZ, José Canosa. A iluminação da Arquitetura e Seu Impacto Sobre a Cidade - City Beautification, Rio de Janeiro: Lume Arquitetura, 2005. Disponível em: <http://www.iar.unicamp.br/lab/ luz/ld/Arquitetural/artigos/02\%20-\%20pro_fachadas_Vis\%E3o_Geral.pdf $>$. Acesso em: 5 de novembro de 2016.

PINTO, Ricardo. Paul Jablochkoff. Lisboa: Universidade Católica Portuguesa ,2008. Disponível em: <http://www.wikienergia.pt/ edp/index.php?title=Paul_Jablochkoff >. Acesso em: 11 de outubro de 2016.

ROSSO, Maurizio. Experience of Lighting Sustainability in the Environment. Milan: Politecnico de Milano, 2012.

SILVA, Lourenço Lustosa Fróes da. Iluminação Pública no Brasil: Aspectos Energéticos e Institucionais. Rio de Janeiro: Universidade Federal do Rio de Janeiro, 2006.

VARGAS, Cláudia Rioja de Aragão. Os impactos da iluminação: visão, cognição e comportamento, São Paulo: Revista Lumière, 2011. Disponível em: <http://www.iar.unicamp.br/lab/luz/ld/Sa\%FAde/artig os/os_impactos_da_iluminacao_visao_congnicao_e_comportamento.pdf $>$. Acesso em: 6 de novembro de 2016.

WILliANS, Sérgio. A Iluminação Pública. Santos: Fundação Arquivo e Memória, 2016.

¿1] Bacharel em Arquitetura e Urbanismo (2013); Tecnóloga em Design de Interiores (2014); PósGraduada em Master em Arquitetura e Iluminação (2016);

\section{PUBLIQUE SEU ARTIGO CIENTÍFICO EM:}

https://www.nucleodoconhecimento.com.br/enviar-artigo-cientifico-para-submissao 